\title{
The investigation of displacement demands of single degree of freedom models using real earthquake records compatible with TBEC-2018
}

\section{Tek serbestlik dereceli modellerde yer değiştirme talebinin TBDY-2018 uyumlu gerçek ivme kayıtları kullanılarak incelenmesi}

\author{
Mehmet PALANCI ${ }^{1}$ iD , Ahmet DEMIR ${ }^{2 *}$ iD , Ali Haydar KAYHAN ${ }^{3}$ iD \\ 1Department of Civil Engineering, Engineering-Architecture Faculty, İstanbul Arel University, Istanbul, Turkey. \\ mehmetpalanci@arel.edu.tr \\ 2Department of Civil Engineering, Engineering Faculty, Bolu Abant İzzet Baysal University, Bolu, Turkey. \\ ahmetdemir@ibu.edu.tr \\ 3Department of Civil Engineering, Engineering Faculty, Pamukkale University, Denizli, Turkey. \\ hkayhan@pau.edu.tr
}

\section{Abstract}

Advances in earthquake engineering play a role in the development of seismic codes all over the world. The new version of Turkish Building Earthquake Code (TBEC) has also been published in 2018. Thanks to the technological developments, real acceleration records to be used in dynamic analysis of structures have been easily accessible. In this study, the variation of maximum displacement demands of single degree of freedom (SDOF) systems determined via dynamic analysis by using real earthquake records compatible with TBEC are investigated. For this purpose, 120 SDOF systems which represent behavior of variety of structural topologies were created by combination of different lateral strength capacity ratios, structural periods, hysteretic models and postyield stiffness ratios. In order to obtain ground motion records, two different level of seismic intensity level and three different local soil classes are considered. 30 real ground motion record sets for each seismic intensity level and local soil class are used for detailed assessment of tendency and variation of maximum displacement demands. Results indicated that (a) effect of different hysteretic models on displacement demands is negligible, (b) the mean displacement demands are more conservative than median displacement demands for the sets, (c) displacement demand variation of the sets are high and not evenly distributed, (d) the variation of the demands changes randomly depending on local soil class and earthquake level, (e) lateral strength ratio and post-yield stiffness are efficient on the variation of the demands.

Keywords: Single degree of freedom models, Real ground motion record selection, Dynamic analysis, Turkish building earthquake code 2018.

\section{Introduction}

Structural design or assessment of structures can be achieved by performance and/or displacement-based approaches which first is introduced in SEAOC Vision 2000 [1],[2]. In order to perform such a task, the maximum displacement demands are mostly required as an engineering demand parameter.

One of the preferred and reliable analysis methods of determining displacement demand is nonlinear dynamic analysis (NDA). In this method, buildings are generally modeled as two or three-dimensional (2D-3D) and they are subjected to real, simulated or artificial earthquake records [3]-[5].
Öz

Deprem mühendisliğindeki gelișmeler, tüm dünyada deprem yönetmeliklerinin gelişmesinde rol oynamaktadır. Türkiye Bina Deprem Yönetmeliği'nin (TBDY) yeni versiyonu da 2018 yılında yayınlanmıștır. Teknolojik gelişmeler sayesinde, yapıların dinamik analizinde kullanılacak gerçek ivme kayıtları kolay ulaşılabilir hale gelmiştir. Bu çalışmada, tek serbestlik dereceli (TSD) sistemlerin TBDY ile uyumlu gerçek ivme kayıtları kullanılarak yapılan dinamik analizi ile elde edilen maksimum yerdeğiștirme taleplerinin değișimi incelenmiștir. Bu amaçla, çeşitli yapı özelliklerini dikkate almaya olanak sağlayan 120 TSD sistem modeli, farkl y yatay dayanım oranı, titreșim periyodu, histeretik davranış modeli ve akma sonrası rijitlik değerlerinin kombinasyonu ile elde edilmiștir. İvme kayıtlarının elde edilmesi için iki farklı deprem seviyesi ile beraber üc farklı yerel zemin sinıfi dikkate alınmıştır. Maksimum yerdeğiștirme taleplerinin eğilimi ve saçılımını detaylı olarak değerlendirmek amacıyla her bir deprem seviyesi ve yerel zemin sınıfı için 30 gerçek ivme kaydı seti kullanılmıştır. Sonuçlar, (a) cevrimsel modellerin etkisinin ihmal edilebileceğini, (b) sete ait ortalama taleplerin, medyan taleplere göre daha yüksek olduğunu, (c) taleplerin set içindeki saçılımının yüksek ve değişkenlik gösterdiğini, (d) talep saçılımında yerel zemin sınıfi ve/veya deprem yer hareketi etkisinin olmadı̆̆ı ve rastgele değiștiğini, (e) yatay dayanım oranı ve akma sonrası rijitliğin taleplerin saçılımı üzerinde etkili olduğunu, göstermiştir.

Anahtar kelimeler: Tek serbestlik dereceli modeller, Gerçek ivme kaydı seçimi, Dinamik analiz, Türkiye bina deprem yönetmeliği 2018.

\footnotetext{
${ }^{*}$ Corresponding author/Yazışılan Yazar
} 
building types [7]-[13]. Riddel et al. [7] used three different hysteretic models (bilinear with/without hardening and stiffness degrading models) to investigate effect of hysteretic models using NDA. Hatzigeorgiou and Beskos [8] used repeated earthquakes to obtain displacement demands of SDOF buildings and empirical equations were presented to estimate displacement demands. Kayhan and Demir [9] used four different hysteretic models (bilinear with/without hardening, modified takeda and stiffness degrading models) to assess effect of different hysteretic models on the seismic demands of SDOF systems using code-compliant earthquakes [14]. Balzopoulo et al. [15] developed a computer program called DYANAS to perform NDA of SDOF systems using different hysteretic models. It can be understood from the above studies that different hysteretic models are utilized by different researchers. The most utilized models are bilinear (BL) [16] and Modified Clough (MC) model to represent behavior of reinforced concrete buildings [17]. The use of different hysteretic models is also important to define behavior of distinct building types [18],[19]

In addition to representation of structural behavior, the use of ground motion records in the analysis of structures in time domain is also utmost important. The selected earthquakes should at least represent the seismicity of site the where the building constructed and they should be compatible with local soil class of building site to estimate reliable displacement demands for the building [20]. In general, three types of accelerograms are used: artificial, simulated or real earthquakes. Artificial and simulated records tend to lack of time-varying intensity and frequency content of earthquake characteristics that dramatically influence the structural response. For this reason, researchers are sought to use real earthquakes [21]-[23] in recent years. It is also worth to state that it is possible to access multiple online digital databases [24]-[26] and hence, huge amount of strong motion records from the websites can be utilized for the analysis of structures. Turkish Building Earthquake Code (TBEC) [27] also recommends using artificial, simulated and real earthquakes for the analysis of structures. However, it is obligated that selected records should satisfy the seismicity and local site conditions where the building is located. In addition, it expected that selected records should be compatible with target spectrum of the building site between the $0.2 T$ and $1.5 T$ where $T$ describes the first mode vibration period of the building.

Considering the importance of record selection for building evaluation and above-mentioned studies, mean displacement demands and their variation is evaluated in this study by different real record sets and hysteretic models using TBEC record selection approach. Two different earthquake intensity levels (DD1 and DD2) and three (ZB, ZC and ZD) soil types defined in TBEC are used for detailed assessment purposes. DD1 and DD2 describe the earthquake levels that have $2 \%$ and $10 \%$ probability of exceedance in 50 years, respectively. For each earthquake intensity level and local soil type, 30 real earthquake record sets compatible with TBEC target spectrum is used and in total 360 different earthquake sets are obtained. In the scope of the study, totally 120 different SDOF systems which are different periods, lateral strength capacity ratios $\left(V_{t} / W\right)$, hysteretic models and post-yield stiffnesses used and analyzed. Periods are ranging from $0.5 \mathrm{~s}$ to $2.0 \mathrm{~s}$ and lateral strength capacity ratios $\left(V_{t} / W\right)$ range between 0.10 and 0.30 for SDOF systems. Nonlinear behaviour of SDOF systems was also represented by distinct BL and MC hysteretic models. In addition, post-yield behavior of these models was also diversified by the ratio of yield stiffness to post-yield stiffness and three distinct ratios $(0.00,0.05$ and 0.10$)$ are used. From NDA of SDOF systems for each set, displacement demands and their variations are calculated. The obtained results are then compared and evaluated for all parameters considered in this study. During the evaluations, mean and median responses of the record sets were also investigated.

\section{SDOF systems and hysteretic models}

In Eq. (1), equation of the motion of structures is given. In the equation, $u(t), \dot{u}(t)$ and $\ddot{u}(t)$ describe the displacement, velocity and acceleration responses. $\ddot{u}_{g}(t)$ is the acceleration history of the earthquake. For the analysis of SDOF systems, three main components should be described: stiffness $(k)$, mass $(\mathrm{m})$ and damping $(c)$. In the study, it is assumed that $c=5 \%, m=1$ and $k$ is calculated according to given $T$. In Figure $1 \mathrm{a}$, general behaviour of SDOF systems subjected to earthquake is illustrated.

$$
m \ddot{u}(t)+c \dot{u}(t)+k u(t)=-m \ddot{u}_{g}(t)
$$

In this study, wide range of structural topologies are represented by two structure-related parameters: $V_{t} / W$ and $T$. Structural periods $(T)$ of the SDOF systems are varied between $0.5 \mathrm{~s}-2.0 \mathrm{~s}$ with increments of $0.5 \mathrm{~s}$. By this way, the dominant vibration period of low to high rise buildings are accounted in the analyses. In addition, different structural topologies which results different behavior on the structures represented by lateral strength capacity ratios $\left(V_{t} / W\right)$ and wide range of ratios $(0.10,0.15,0.20,0.25$ and 0.30$)$ that covers old and new type of structures, are recognized. It can be said that low $V_{t} / W(<0.20)$ represents old and high $V_{t} / W(\geq 0.20)$ represents new buildings [28],[29]. Furthermore, effect of stiffness degradation is considered using BL and MC hysteretic models. In this way, behavior of different structural systems is taken into account. It can be seen from Figure 1(b) that BL model does not account the stiffness degradation. However, MC (Figure 1(c) accounts the degradation effects. In the figures, yield stiffness is represented by $k$ and post-yield behavior is illustrated by $\alpha$ times of $k . \alpha$ value effects the behavior and if it is positive, it implies the hardening. In literature, different $\alpha$ values are used for the analysis of SDOF systems such as $0.00,0.01,0.03,0.05$ and 0.10 [8],[9]. Considering on the use of this parameter, distinct $(0.00,0.05$ and 0.10$)$ values are used to grasp possible effects of this parameter on the displacement demands.

Consequently, 120 different SDOF systems were analyzed using two hysteretic models with three different post-yield stiffness ratios $(\alpha)$ and 20 different $V_{t} / W$ and $T$ combinations. In Figure 2, typical response of SDOF system for $T=1.0 \mathrm{~s}$ and $V_{t} / W=0.1$ subjected the same real earthquake is sketched for BL and MC models considering three post-yield stiffness ratios $(0.00,0.05$ and 0.10$)$. Stiffness degradation can clearly be observed from the MC models. It can be said from the figure that displacement demands of hysteretic models are almost identical even for the different post-yield stiffness ratios.

\section{Ground motion record sets}

In literature, various studies that use real earthquake records according to different seismic codes can be found (Kayhan et al. [20] and Iervolino et al. [21]). 


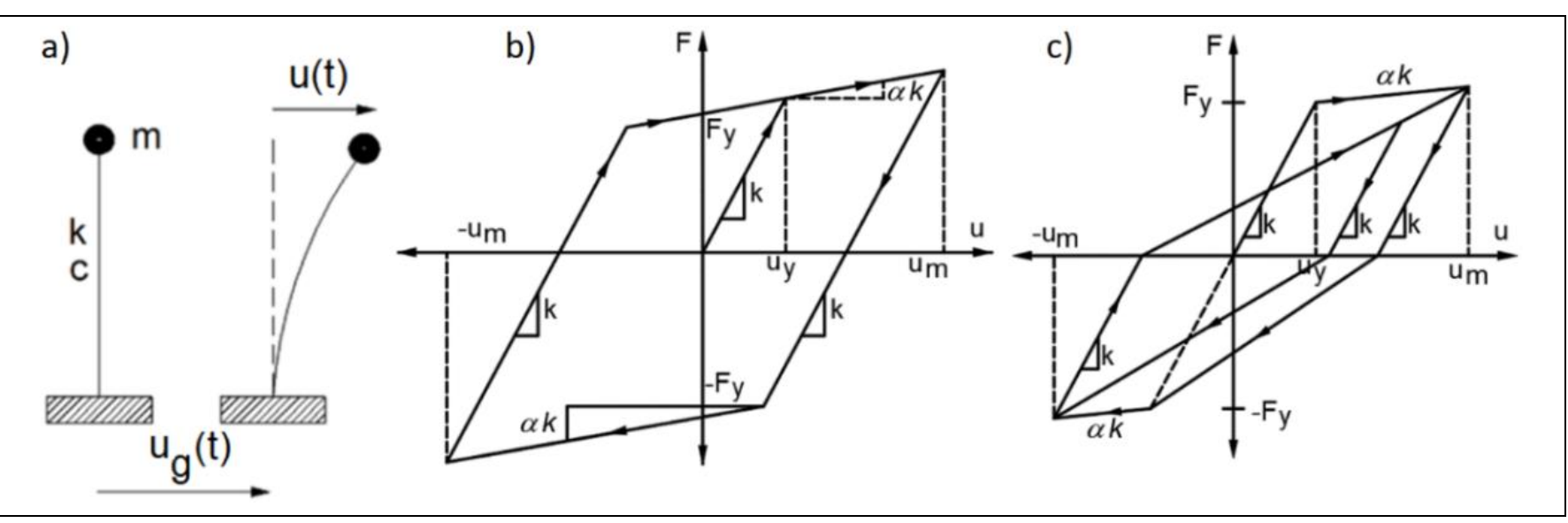

Figure 1. SDOF system and hysteretic models used in this study.

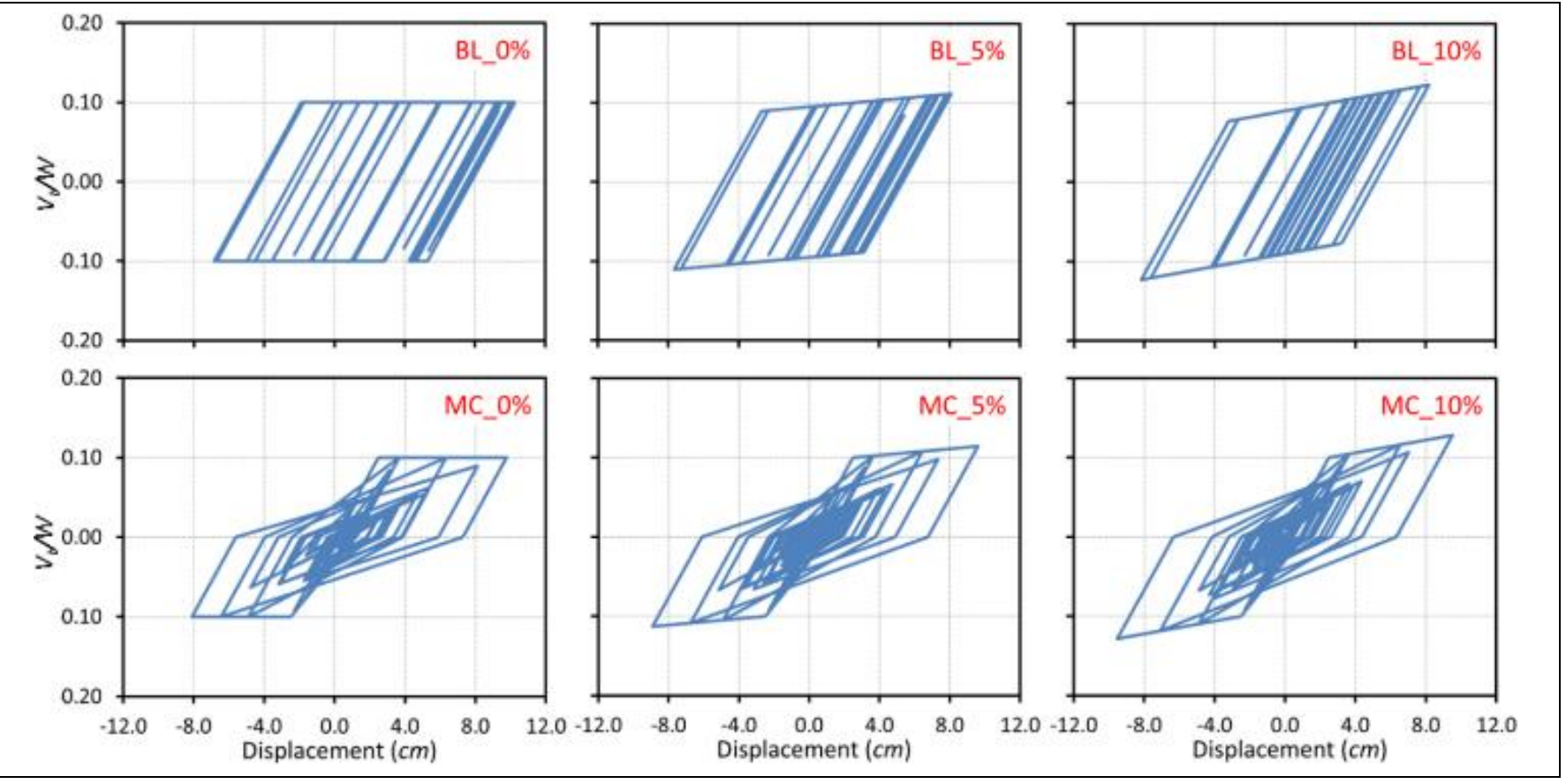

Figure 2. Hysteretic models for all post yielding stiffness subjected to seismic load (Chi-Chi-1999, Peer No: 1182N, $M_{w}=7.62$ ).

In this study, earthquake records sets are obtained using stochastic harmony search based solution algorithm provided by Kayhan [30] according to TBEC target response spectrum using code requirements. Moreover, all the computations about the solution algorithm are performed by developing MSExcel macro code [31].

\subsection{Elastic design spectrum of TBEC}

Information of earthquake intensities for each point of Turkey is provided in the website of AFAD [32]. In TBEC, four different earthquake intensity levels named DD1, DD2, DD3 and DD4 are used. Each intensity level is described in terms of probability of exceedance in 50 years. DD1 and DD4 describe the extreme intensity levels of earthquake events.

Elastic design spectrum can be obtained by using $S_{S}$ and $S_{1}$ coefficients determined according to reference local soil conditions $\left(V_{s 30}=760 \mathrm{~m} / \mathrm{s}\right)$. These values are determined from website given earlier for each point in the seismic hazard map of Turkey. $S_{S}$ and $S_{1}$ represent the short period region and $1.0 \mathrm{~s}$ period region as the ratio of the map spectral accelerations to acceleration of gravity. $S_{S}$ and $S_{1}$ are converted to design spectral acceleration coefficients by Eq. 2 . In Eq. $2, S_{D S}$ and $S_{D 1}$ are short period and 1.0s period design spectral acceleration coefficients, respectively, $F_{S}$ and $F_{1}$ are local soil effect coefficients defined in TBEC depending on the local soil class and map spectral acceleration coefficients. $F_{S}$ and $F_{1}$ values used in this study are given in Table 1.

$$
\begin{aligned}
& S_{D S}=S_{S} F_{S} \\
& S_{D 1}=S_{1} F_{1}
\end{aligned}
$$

$S_{a e}(T)$ which is the ordinate of the horizontal elastic design acceleration spectrum is determined by Eq. 3. In Eq. 3, $T_{A}$ and $T_{B}$ are the corner periods of the design spectrum. $T_{B}$ is determined by ratio of $S_{D 1}$ to $S_{D S}, T_{A}$ can be calculated by 0.2 times of $T_{B}$ and $T_{L}$ is equal to $6.0 \mathrm{~s}$. 
Table 1. Parameters of the target spectra considered in this study.

\begin{tabular}{ccccccccccc}
\hline Earthquake & Soil & $P G A$ & $S_{S}$ & $S_{1}$ & $F_{S}$ & $F_{1}$ & $S_{D S}$ & $S_{D 1}$ & $T_{A}(s)$ & $T_{B}(s)$ \\
\hline \multirow{5}{*}{ DD1 } & ZB & & & & 0.900 & 0.800 & 1.904 & 0.407 & 0.043 & 0.214 \\
& ZC & \multirow{2}{*}{0.836} & \multirow{2}{*}{2.115} & \multirow{2}{*}{0.509} & 1.200 & 1.491 & 2.538 & 0.759 & 0.060 & 0.299 \\
& ZD & & & & 1.000 & 1.791 & 2.115 & 0.912 & 0.086 & 0.431 \\
\hline \multirow{3}{*}{ DD2 } & ZB & & & & 0.900 & 0.800 & 1.016 & 0.208 & 0.041 & 0.205 \\
& ZC & \multirow{2}{*}{0.461} & \multirow{2}{*}{1.129} & \multirow{2}{*}{0.260} & 1.200 & 1.500 & 1.355 & 0.390 & 0.058 & 0.288 \\
& ZD & & & & 1.048 & 2.080 & 1.183 & 0.541 & 0.091 & 0.457 \\
\hline
\end{tabular}

In this study, elastic design spectrum of DD1 and DD2 which have return period of 2475 years and 475 years are used, respectively. For the description of elastic design spectrum, the coordinates of Denizli Municipality are (Latitude: 37.7734 , Longitude: 29.0867) considered. The spectrum of DD1 and DD2 considering ZB, ZC and ZD soil types are given in Figure 3. Required information for the derivation of these spectra is given in Table 1.

$$
\begin{array}{rlrl}
S_{a e}(T) & =\left(0.4+0.6 \frac{T}{T_{A}}\right) S_{D S} & \left(0 \leq T \leq T_{A}\right) \\
S_{a e}(T)=S_{D S} & \left(T_{A} \leq T \leq T_{B}\right) \\
S_{a e}(T)=\frac{S_{D 1}}{T} & \left(T_{B} \leq T \leq T_{L}\right) \\
S_{a e}(T)=\frac{S_{D 1} T_{L}}{T^{2}} & \left(T_{L} \leq T\right)
\end{array}
$$

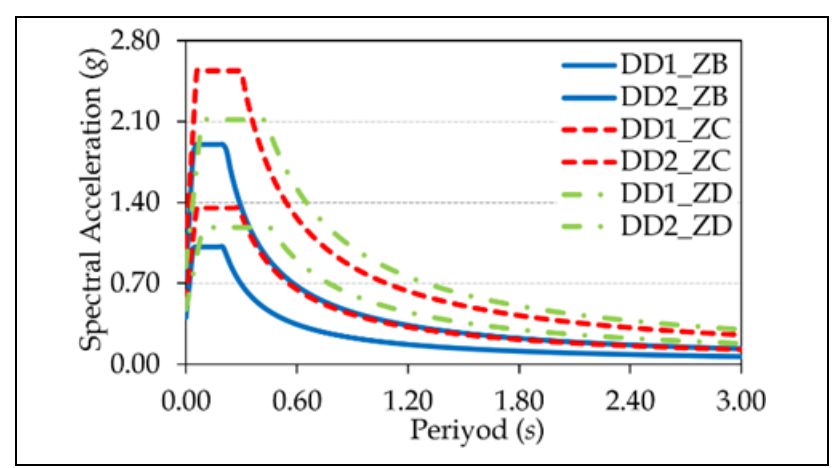

Figure 3. Target spectra used in this study.

\subsection{Strong ground motion database}

Ground motion record sets of current study are obtained using real ground motion records. For this purpose, it is important to collect numerous of real earthquakes from the different databases provided online from the web. Real ground motion database can be collected according to seismic parameters such as peak ground acceleration $(P G A)$, earthquake magnitude $\left(M_{w}\right)$, epicentral distance $(R)$, shear wave velocity $\left(V_{s 30}\right)$ etc. In this study, database is created according to $M_{w}, R$ and $V_{s 30}$. The $V_{s 30}$ of soil classes considered in this study are between $760 \mathrm{~m} / \mathrm{s}$ and $1500 \mathrm{~m} / \mathrm{s}$ for ZB, $360 \mathrm{~m} / \mathrm{s}$ and $760 \mathrm{~m} / \mathrm{s}$ for ZC and $180 \mathrm{~m} / \mathrm{s}$ and $360 \mathrm{~m} / \mathrm{s}$ for ZD.

Three different databases; European Strong Motion Database (ESMD) [24], Resorce [25] and Pacific Earthquake Engineering Research Center (PEER) [26] are used. Ground motion catalogs are first created for each local soil class. Then, ground motions are selected from the corresponding local soil class and record sets are obtained. In the catalog, mid and high intensity earthquakes are considered $\left(M_{w}>5.0\right)$. In addition, ground motions which have epicentral distance $(R)$ between
10 and $60 \mathrm{~km}$ are used. Total number of ground motions in the catalog according to their magnitude, distance and local soil class is given in Table 2. It can be observed from the table that 203 record pairs (406 components) are determined for ZB. ZC has 1053 pairs or 2106 components and ZD has 782 pairs or 1564 horizontal components.

Table 2. Properties of the records in the catalog.

\begin{tabular}{cccccccc}
\hline Soil & $M_{w} / R$ & $10-20$ & $20-30$ & $30-40$ & $40-50$ & $50-60$ & Total \\
\hline \multirow{6}{*}{ ZB } & $5.0-5.5$ & 26 & 26 & 11 & 8 & 4 & \\
& $5.5-6.0$ & 11 & 15 & 10 & 5 & 16 & \\
& $6.0-6.5$ & 2 & 13 & 7 & 7 & 10 & 203 \\
& $6.5-7.0$ & 1 & 11 & 8 & 5 & 5 & \\
& $7.0-7.5$ & - & - & - & 1 & 1 & \\
& $7.5-8.0$ & - & - & - & - & - & \\
\hline \multirow{6}{*}{ ZC } & $5.0-5.5$ & 60 & 49 & 38 & 38 & 40 & \\
& $5.5-6.0$ & 58 & 36 & 31 & 33 & 37 & \\
& $6.0-6.5$ & 45 & 42 & 59 & 77 & 101 & 1053 \\
& $6.5-7.0$ & 36 & 34 & 34 & 56 & 53 & \\
& $7.0-7.5$ & 6 & 12 & 8 & 10 & 8 & \\
& $7.5-8.0$ & 4 & 8 & 13 & 17 & 10 & \\
\hline \multirow{6}{*}{ ZD } & $5.0-5.5$ & 61 & 39 & 40 & 28 & 23 & \\
& $5.5-6.0$ & 43 & 36 & 37 & 12 & 27 & \\
& $6.0-6.5$ & 29 & 12 & 32 & 50 & 53 & 782 \\
& $6.5-7.0$ & 28 & 43 & 38 & 40 & 40 & \\
& $7.0-7.5$ & 8 & 7 & 7 & 9 & 12 & \\
& $7.5-8.0$ & 1 & 2 & 8 & 10 & 7 & \\
\hline
\end{tabular}

3.3 Records selection according to TBEC and additional selection criteria

According to TBEC, selected earthquakes compatible with elastic design spectrum should satisfy the $M_{w}, R$, soil conditions and fault mechanism of the site interest. In addition, following requirements are also given:

- At least, eleven ground motions should be used for uni/bidirectional analysis,

- Maximum number of earthquakes selected from the same earthquake event should not exceed three,

- Mean acceleration spectrum of selected earthquakes should not be lower than elastic acceleration spectrum between the periods of $0.2 T$ ve $1.5 T$ ( $T$ is the period of the building) and accordingly selected earthquake records can be scaled in amplitude domain.

In addition to requirements of the TBEC, following constraints are attained for the selected earthquakes and the sets in this study:

- Only one horizontal component of the same record is allowed in the sets.

- Scale factor was limited between 0.50 and 2.00 for selected earthquakes. 
To increase compatibility of spectral shape of selected earthquakes and target spectrum, upper bound is assigned to mean spectrum of selected earthquakes since only lower bound is required according to TBEC. Maximum limit is taken equal to 1.2 for mean spectrum of record sets.

\subsection{Attributes of earthquake record sets}

30 different real earthquake record sets are used for each target spectrum. Total of 180 earthquake record sets are obtained for each of SDOF system using different earthquake levels (DD1, DD2) and local soil type (ZB, ZC and ZD). Since four structural periods $(0.5,1.0,1.5,2.0)$ are considered for SDOF systems, selected record set are compatible with target spectrum between periods of $0.1 \mathrm{~s}$ and $3.0 \mathrm{~s}$.

The first record sets of DD2 for each local soil type are given in Table 3 with earthquake number and scale factors for illustration. As can be checked from the table that only one component of same earthquake is used in the record sets. For example, it is not possible to observe $665 \mathrm{x}$ and $665 \mathrm{y}$ components in the same record set. It can also be observed that extreme values of scale factor are 1.998 for ZB applied to $879 \mathrm{y}$ and 0.729 for ZC applied to 81y component.

In Figure 4, individual and mean spectrum of first record set are shown for each soil type and earthquake level with corresponding target spectrum. As can be observed from the
Figure 4 that obtained record set satisfy the all assigned constraints given earlier.

In Figure 5, on the other hand, mean spectrum of all record sets are illustrated for each soil type and earthquake level. It can be seen from the Figure 5 that mean spectrum of 30 different record set ranges between 1.0-1.2 times of target spectrum as described during the stochastic selection procedure.

Table 3. The first sets of DD2 earthquake level.

\begin{tabular}{cccccc}
\hline \multicolumn{2}{c}{ ZB } & \multicolumn{2}{c}{ ZC } & \multicolumn{2}{c}{ ZD } \\
\hline Rec & Sca & Rec & Sca & Rec & Sca \\
\hline $665 \mathrm{x}$ & 1.198 & $4218 \mathrm{y}$ & 1.438 & $4894 \mathrm{y}$ & 1.183 \\
$146 \mathrm{x}$ & 1.743 & $1085 \mathrm{x}$ & 1.107 & $4134 \mathrm{y}$ & 1.421 \\
$7142 \mathrm{y}$ & 1.317 & $1126 \mathrm{x}$ & 1.238 & $1244 \mathrm{y}$ & 1.426 \\
$879 \mathrm{y}$ & 1.998 & $3966 \mathrm{y}$ & 1.793 & $695 \mathrm{y}$ & 1.975 \\
$766 \mathrm{x}$ & 1.821 & $81 \mathrm{y}$ & 0.729 & $999 \mathrm{x}$ & 1.134 \\
$7187 \mathrm{y}$ & 0.962 & $825 \mathrm{y}$ & 1.946 & $1063 \mathrm{x}$ & 1.702 \\
$6115 \mathrm{y}$ & 1.216 & $340 \mathrm{x}$ & 1.548 & $677 \mathrm{x}$ & 0.958 \\
$196 \mathrm{x}$ & 0.909 & $5806 \mathrm{x}$ & 1.857 & $5777 \mathrm{x}$ & 1.928 \\
$287 \mathrm{y}$ & 1.475 & $1551 \mathrm{y}$ & 1.032 & $725 \mathrm{x}$ & 1.770 \\
$6154 \mathrm{x}$ & 1.889 & $4101 \mathrm{x}$ & 1.505 & $126 \mathrm{y}$ & 1.296 \\
$3954 \mathrm{y}$ & 1.483 & $4219 \mathrm{y}$ & 0.773 & $30 \mathrm{y}$ & 1.952 \\
\hline
\end{tabular}
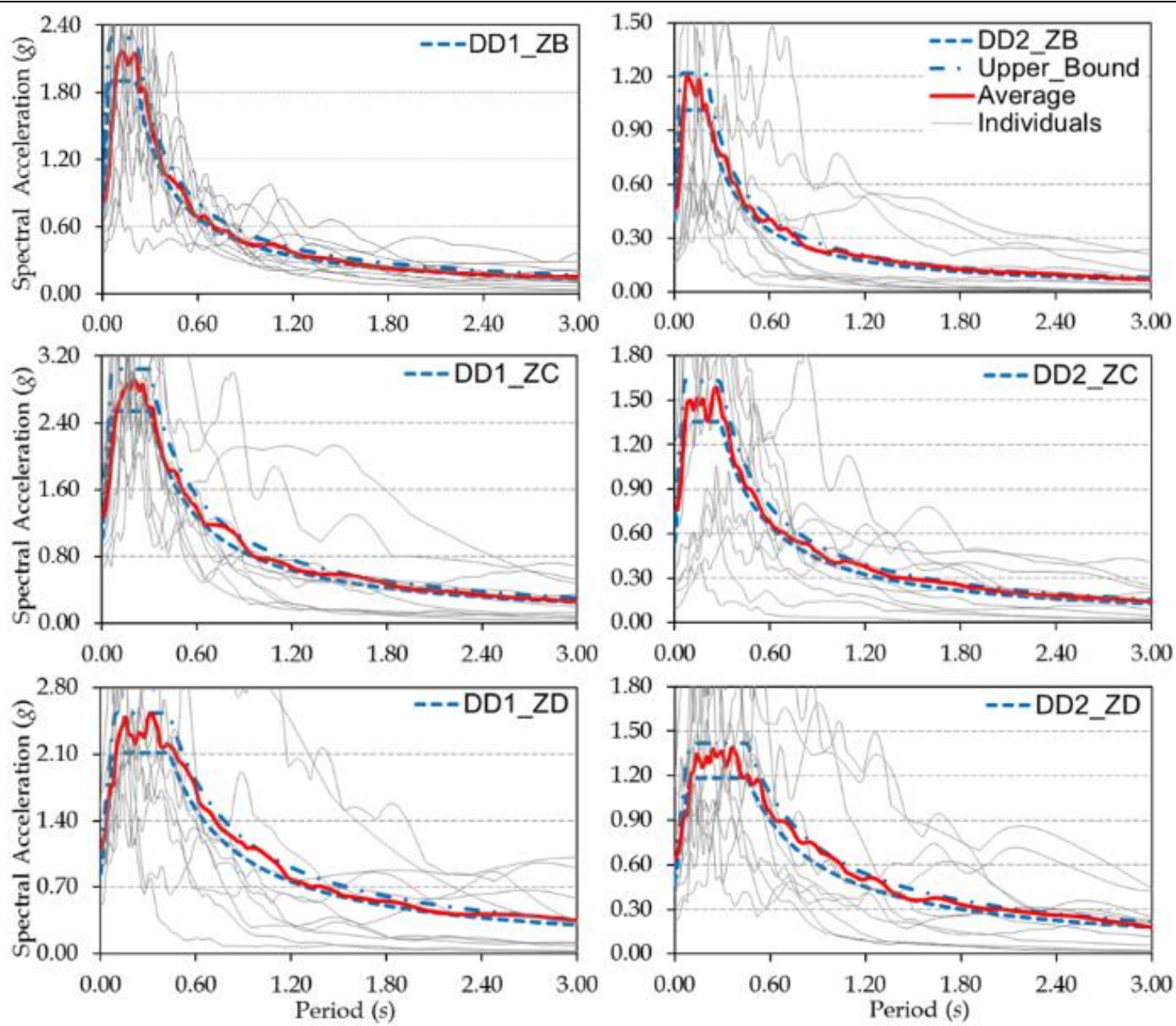

Figure 4. Individual, mean and target spectrum of first sets for all earthquake levels and local soil classes. 

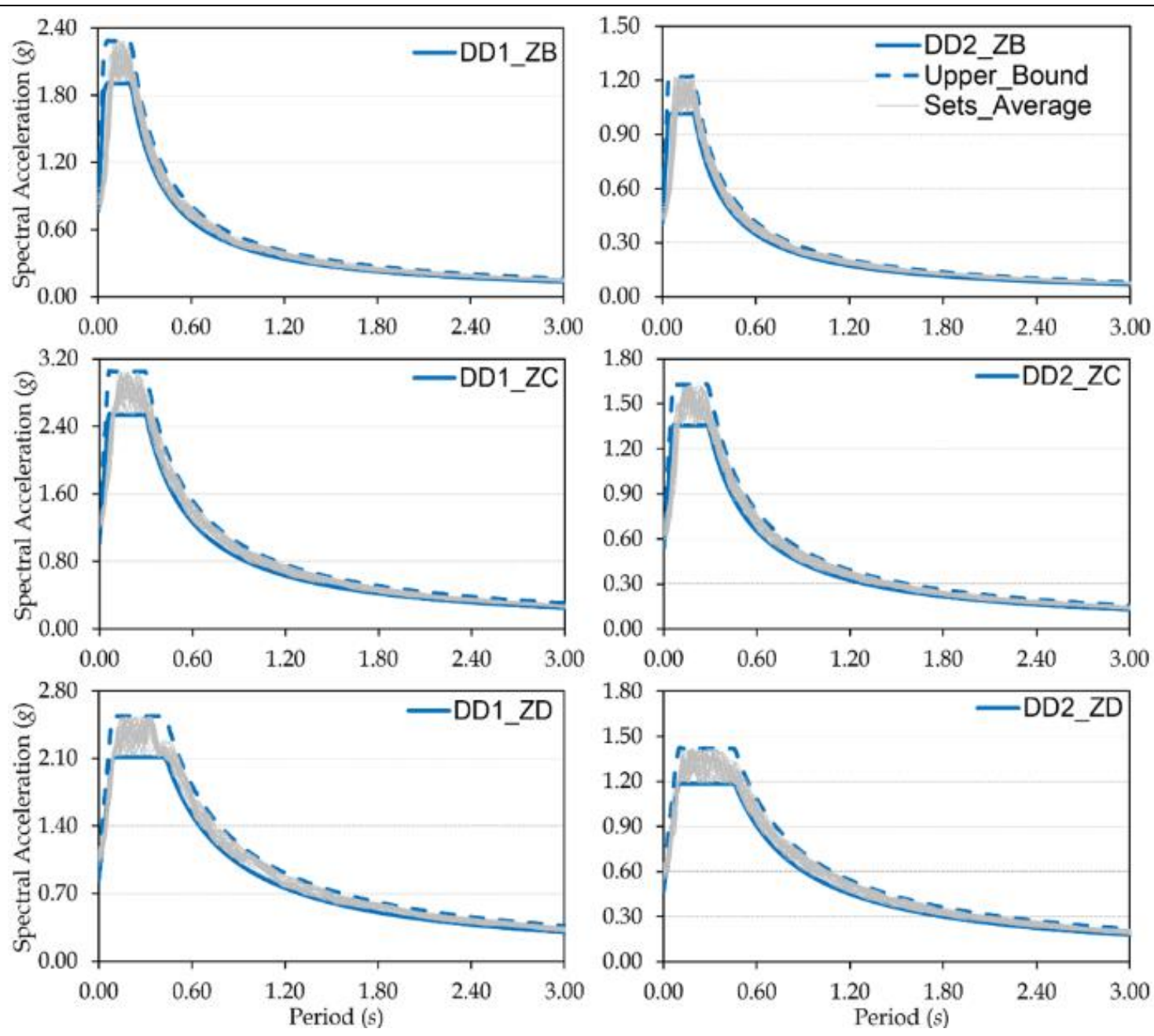

Figure 5. Target spectra and mean spectra of 30 record sets for all earthquake levels and local soil classes.

\section{Analysis results}

Maximum displacement demands $\left(\Delta_{\max }\right)$ of 120 SDOF models with different lateral strength capacity ratios, structural periods and hysteretic models and post-yield stiffnesses are computed using 180 different earthquake record sets. Accordingly, 237,600 nonlinear dynamic analyses were performed. According to TBEC, mean of maximum displacement demands of individual records in the set should be used. Thus, mean displacement demand $\left(m_{\Delta}\right)$ of each record set is computed by averaging the eleven displacement demands. For each SDOF model and soil class, the mean of all (30) $m_{\Delta}$ values are calculated as expected value of them $\left(\mu_{m}\right)$.

To evaluate variation of displacement demands in the set, standard deviation $\left(s_{\Delta}\right)$ and the coefficient of variation $\left(\mathrm{CoV}_{\Delta}\right)$ of set is also computed. Since 30 different earthquake record sets is used, mean of 30 record sets is calculated (as expected value of $30 \mathrm{CoV}_{\Delta}$ ) and notated as $\mu_{\mathrm{CoV}}$. Furthermore, median responses of the record sets are determined from the analyses and compared with mean responses.

In Figure 6, maximum displacement demands of SDOF systems with $V_{t} / W=0.1$ are given for $T=0.5 \mathrm{~s}$ and $2.0 \mathrm{~s}$ separately according to soil ZB and hysteretic model BL without post yield stiffness ratio $(\alpha=0.00)$. In the figure, maximum displacement demand of each ground motion records, mean (black dotted line) and median (grey dotted line) results of the sets are shown. For example, maximum displacement demands of individual records in the first set for $T=0.5 \mathrm{~s}$ are $4.42,7.47,9.08,7.67,3.44,6.19,6.70,22.22,7.63,8.66$ and $5.06 \mathrm{~cm}$. The mean and median of these individual demands are $8.05 \mathrm{~cm}$ and $7.47 \mathrm{~cm}$, respectively. It is worth to state that the mean demand of set is higher than median demand.

If Figure 6 is observed for all record sets, it can be mentioned that displacement demands are randomly distributed and different responses can be determined from the different record sets. For example, mean displacement demands from Set1 to Set5 are $8.05,11.63,9.88,9.44$ and $8.79 \mathrm{~cm}$, respectively. Mean of 30 record sets $\left(\mu_{m}\right)$ for $T=0.5 \mathrm{~s}$, on the other hand, is equal to $9.92 \mathrm{~cm}$. However, it can be stated that median demands are generally lower than mean demands of sets. Similar conclusions can also be drawn for $T=2.0$ s. It can be told that application of appropriate upper limit for the mean spectrum may be used to control mean displacement demands even if the record selection procedure is stochastic. 


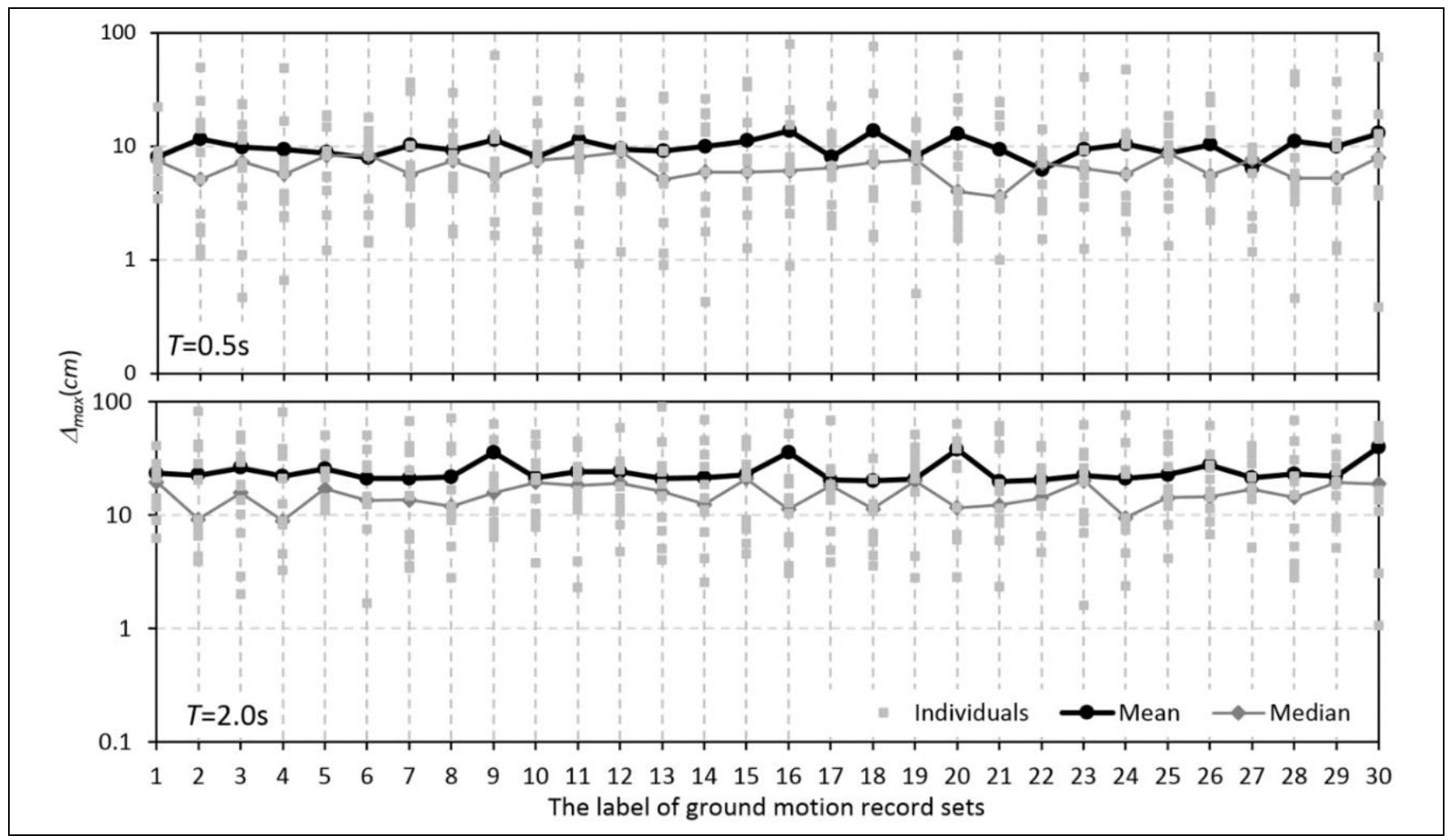

Figure 6. Maximum displacement demands for ZB soil class and DD1 earthquake level $\left(B L_{-} \alpha=0, V_{t} / W=0.1\right)$.

If these calculations are extended for all local soil types, SDOF systems and earthquake levels, we get the results as shown in Figs. 7 and 8 according to expected mean responses of 30 record sets. In Figure 7, $\mu_{m}$ values are given for DD1 level considering different local soil type, $V_{t} / W, T$ and hysteretic model. In the figure different colors are used to represent different structural periods and line types are varied for hysteretic models. In the figures, notations are given in terms of hysteretic model and $T$ like BL_T $T=0.5 \mathrm{~s}$ and $\mathrm{MC}_{-} T=0.50 \mathrm{~s}$ which represent the results of $T=0.5 \mathrm{~s}$ system considering Bilinear and Modified Clough hysteretic model, respectively. Effect of post yield stiffness ratio and local soil type on mean displacement demands is illustrated from left to right and top to down, respectively.

It is known fact that displacement demands increase with increasing periods and this is apparently seen from Figure 7. In general, displacement demands are decreasing with increasing $V_{t} / W$ especially for lower structural periods. However, this can not be observed for high structural periods. It should be emphasized that displacement demands are increasing from stiff to soft soil types. In addition, effect of different hysteretic model on the seismic demands is limited. For example, while $m_{\Delta}$ values from $V_{t} / W=0.1$ to $V_{t} / W=0.3$ are $24.24,23.00,21.93,21.67$ and $21.76 \mathrm{~cm}$ for BL, these values are $22.74,22.42,21.95,21.83$ and $21.93 \mathrm{~cm}$ for MC considering $T=2.0, \alpha=0$ and ZB. For ZD, $m_{\Delta}$ values from $V_{t} / W=0.1$ to $V_{t} / W=0.3$ were determined as $49.09,50.53,52.73,50.68$ and $49.11 \mathrm{~cm}$ for BL considering $T=2.0, \alpha=0$, but these values were obtained as $49.97,46.46,44.88,46.36$ and $49.65 \mathrm{~cm}$ for MC model. It can be said that seismic demands of BL models may be slightly higher or lower than MC model. Although BL and
MC models quite differ from each other in terms of behavior, seismic demands are not dramatically affected from BL and MC models. This may due the use of SDOF models. However, plastic mechanism of components and hence structure, will certainly affect the demands. Thus, elements of structure should be carefully designed according to capacity-based procedures to control damage of elements.

Displacement demands determined from DD2 is illustrated in Figure 8 for all SDOF systems. Similar trends with DD1 are also viable for DD2 such as alteration of seismic demands with increasing periods and $V_{t} / W$ and hence, the relation between BL and MC model results. If the results of DD1 and DD2 are compared, it can be said that displacement demands determined from DD1 are naturally higher than DD2 earthquake level. Regardless of hysteretic model and lateral strength capacity ratio, $\mu_{m}$ ratio of DD1 to DD2 is range around 1.57-2.18 for ZB, 1.85-2.56 for ZC and 1.86-2.74 for ZB.

In Figure 9, the ratio of expected values of mean displacement demands to expected values of median of 30 different records compatible with the same target spectrum are compared using color index regarding local soil types, earthquake levels and all parameters used in construction of SDOF systems. It can be seen from the coloring index that minimum value of this ratio is higher than 1 which means that mean displacement demands are consistently higher than median demands of the recod sets. In other words, it can be said that consideration of mean responses is more conservative than median responses owing to higher ratios. The minimum of mean/median ratio of BL model is obtained 1.09 for $\mathrm{ZB}, T=0.5 \mathrm{~s}, V_{t} / W=0.3$ and $\alpha=0.10$ while maximum value of this ratio is 2.17 for $\mathrm{ZC}$, $T=2.0 \mathrm{~s}, V_{t} / W=0.1$ and $\alpha=0.00$. 


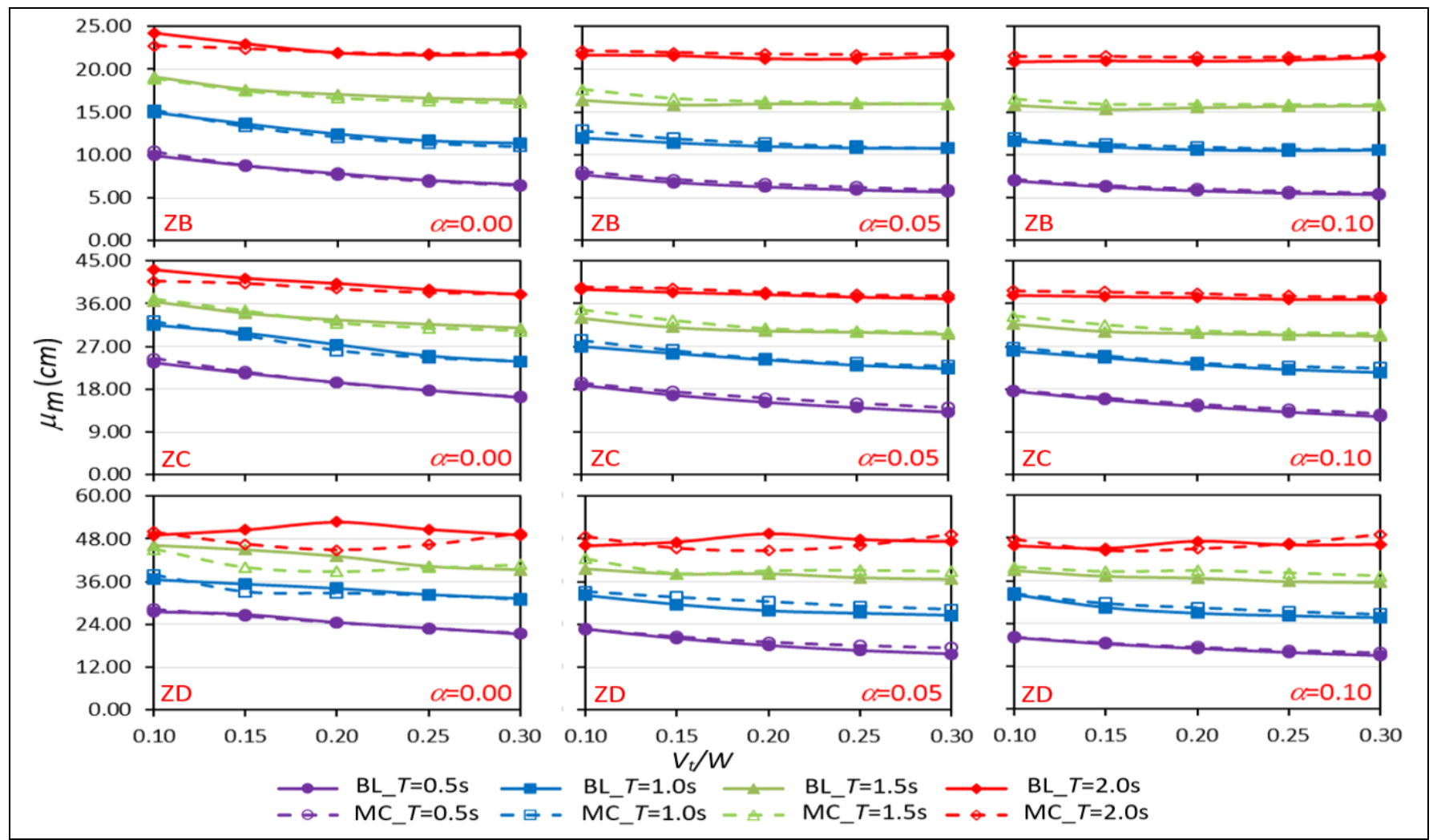

Figure 7. The expected value of $m_{\Delta}$ values of 30 record sets for DD1 earthquake level.

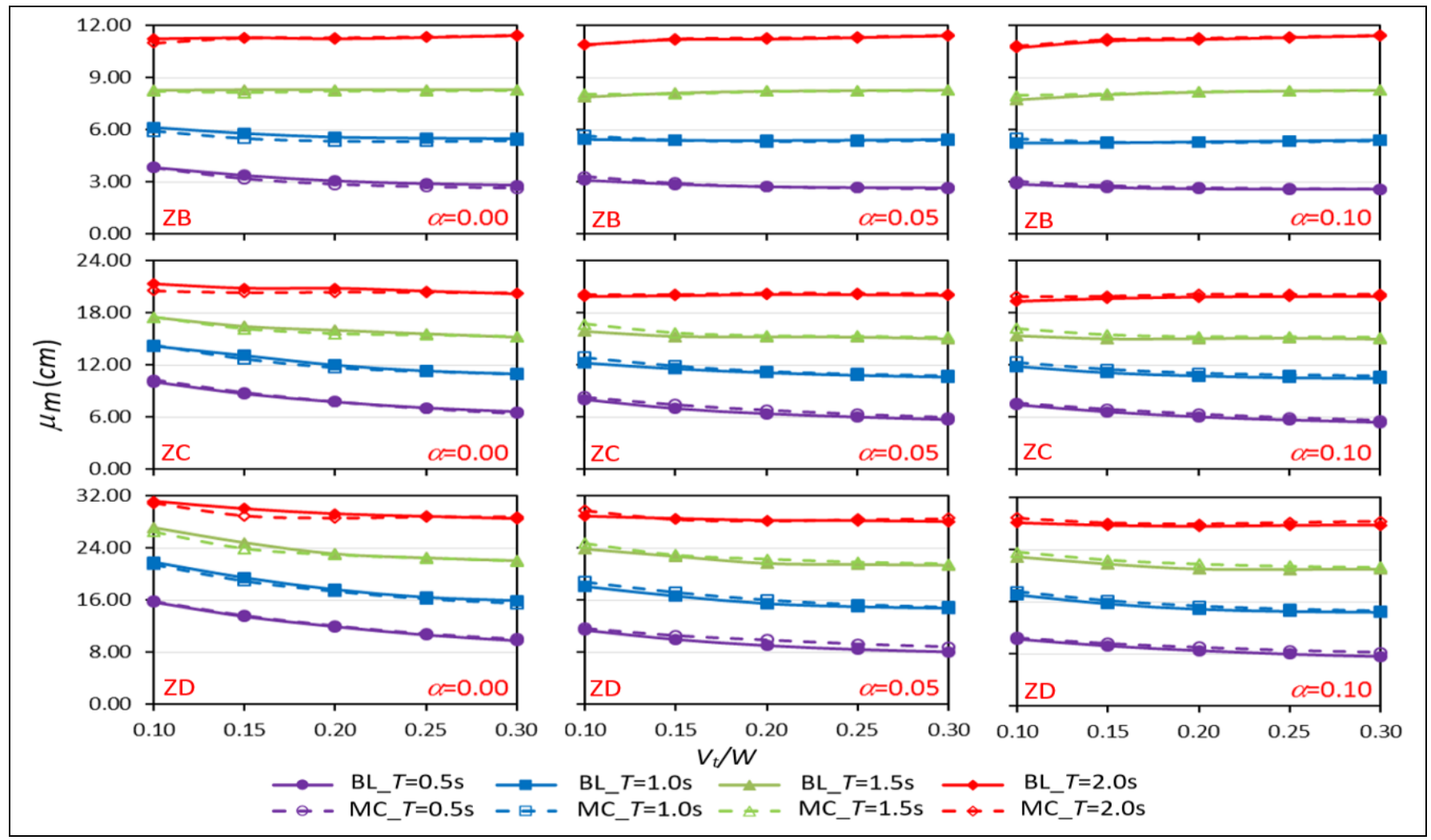

Figure 8. The expected value of $m_{\Delta}$ values of 30 record sets for DD2 earthquake level. 


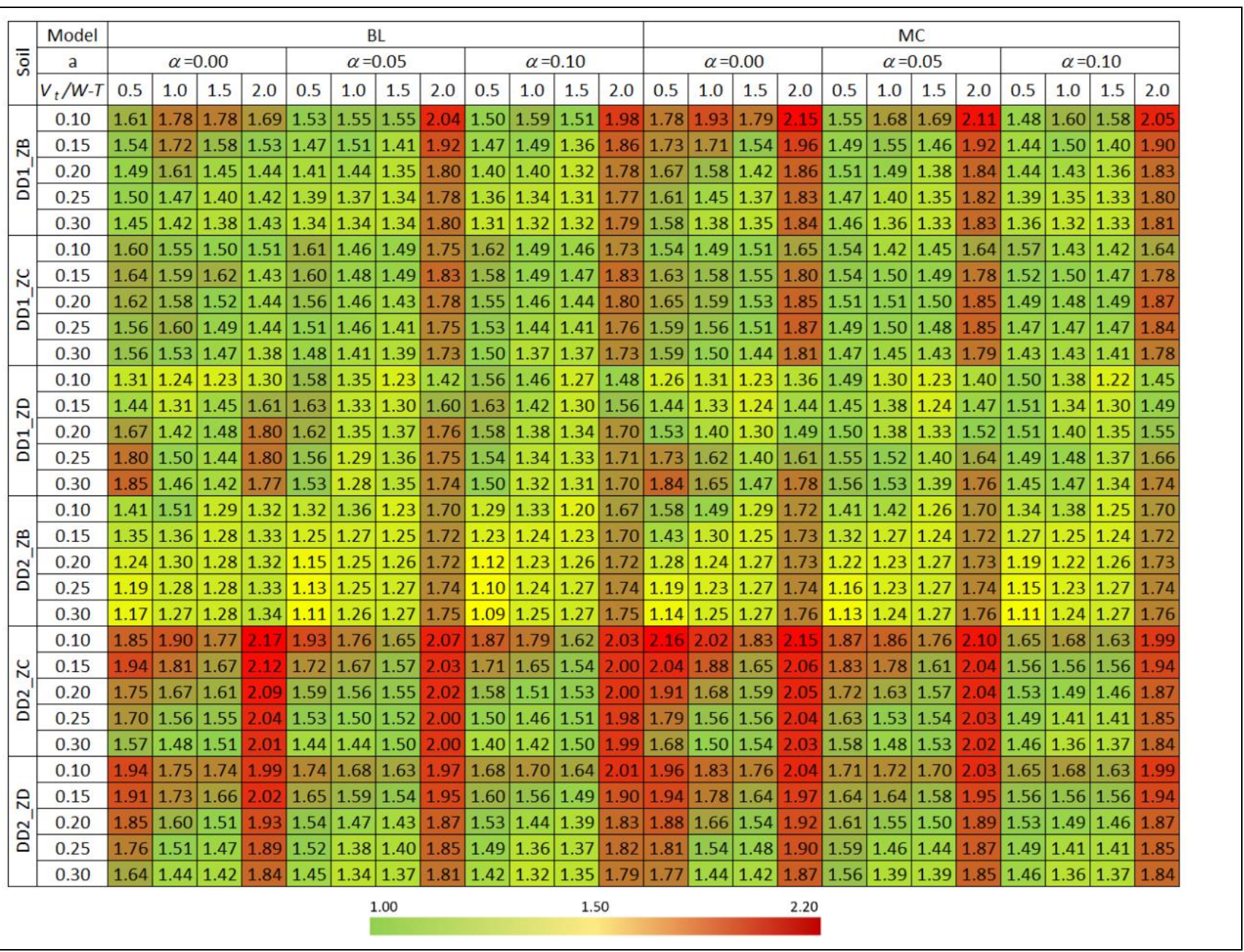

Figure 9. Average of mean to median ratio of all record sets and SDOF models.

Mean/median ratio of MC model is also range around 1.112.16. It can be seen from Figure 9 that the distribution of ratios almost has identical pattern between BL and MC hysteretic models. If the effect of soil type is investigated, it can be realized that the ratios of $\mathrm{ZC}$ and $\mathrm{ZD}$ is relatively higher than ZB. It can be said that distribution of ratios is not influenced by structural periods and it seems that the ratios are randomly distributed except $T=2.0 \mathrm{~s}$. Mean/median ratios are frequently higher than other structural periods. If the ratios are evaluated regarding lateral strength capacity ratios and post yield stiffness ratios, it can be admitted these parameters have not apparent effect on the distribution of ratios.

The scatter of $\mathrm{CoV}_{\Delta}$ values considering DD1, $\alpha=0.00$ and ZB is drawn in Figure 10. In the figure, each point describes $\operatorname{CoV}_{\Delta}$ values of corresponding set and 30 points are plotted in the figure since 30 different record sets are used for each SDOF system, soil type and earthquake level. Red line shows the mean of $\mathrm{CoV}_{\Delta}$ values $\left(\mu_{\mathrm{CoV}}\right)$. For example, extreme values of $\mathrm{CoV}_{\Delta}$ are 0.49 and 1.61 and the rest of these ratio are between these values for $V_{t} / W=0.10$ and $T=0.5 \mathrm{~s}$. If the mean of these ratios are computed, we get 1.01. Distribution of ratios in Figure 10 clearly indicates that displacement demand can be highly distributed. If the scatter of $\mathrm{CoV}_{\Delta}$ values is checked, it can be said the $\mathrm{CoV}_{\Delta}$ values mainly range between 0.5 and 1.5 .
According to Figure 10, it should be noted that $\mu_{\mathrm{CoV}}$ values are not structural period dependent. However, in general, $\mu_{\mathrm{CoV}}$ values seem gradually decreasing with increasing lateral strength capacity ratio. $\mu_{\mathrm{CoV}}$ values of $V_{t} / W=0.15$ are 0.99 , $1.01,0.98$ and 0.95 from 0.5 s to $2.0 \mathrm{~s}$, respectively. In lateral strength capacity ratio case, $\mu_{\mathrm{CoV}}$ values are $1.01,0.99,0.92$, 0.87 and 0.83 from $V_{t} / W=0.1$ to 0.3 , respectively.

$\mu_{\text {CoV }}$ values determined for DD1 and DD2 levels according to all soil types, hysteretic models and related parameters are shown in Figs. 11 and 12, respectively. Results show that mean of variations determined from distinct 30 records sets is quite high for both BL and MC models. Similar conclusions can also be drawn for DD2 level. The minimum of $\mu_{\mathrm{CoV}}$ is 0.7 for $V_{t} / W=0.25, T=2.0$ s and BL_ $\alpha=0.05$ while maximum is 1.17 for $V_{t} / W=0.15, T=0.5 \mathrm{~s}$ BL_ $\alpha=00$ as seen from Figure 11 . On the other hand, Figure 12 indicates that maximum of $\mu_{\mathrm{CoV}}$ determined from ZC is 1.13 for $V_{t} / W=0.10, T=0.5 \mathrm{~s}$ and MC_ $\alpha=0.00$ while minimum determined from ZB is 0.6 for $V_{t} / W=0.15, T=0.5 \mathrm{~s}$ and BL_ $\alpha=0.10$.

It can be implied that $\mu_{\mathrm{CoV}}$ values are generally decreasing for all soil types with increasing post yield stiffness ratio $(\alpha)$ if Figs. 11 and 12 are investigated. Considering $\alpha=0.00$ to $\alpha=0.10, \mu_{C o V}$ values of DD1 (see Figure 11) are 1.01, 0.98 and 0.91 and $\mu_{\mathrm{CoV}}$ values of DD2 (see Figure 12) are $0.92,0.86$ and 0.80 for $V_{t} / W=0.1, T=0.5 \mathrm{~s}, \mathrm{ZB}$ and BL model. 


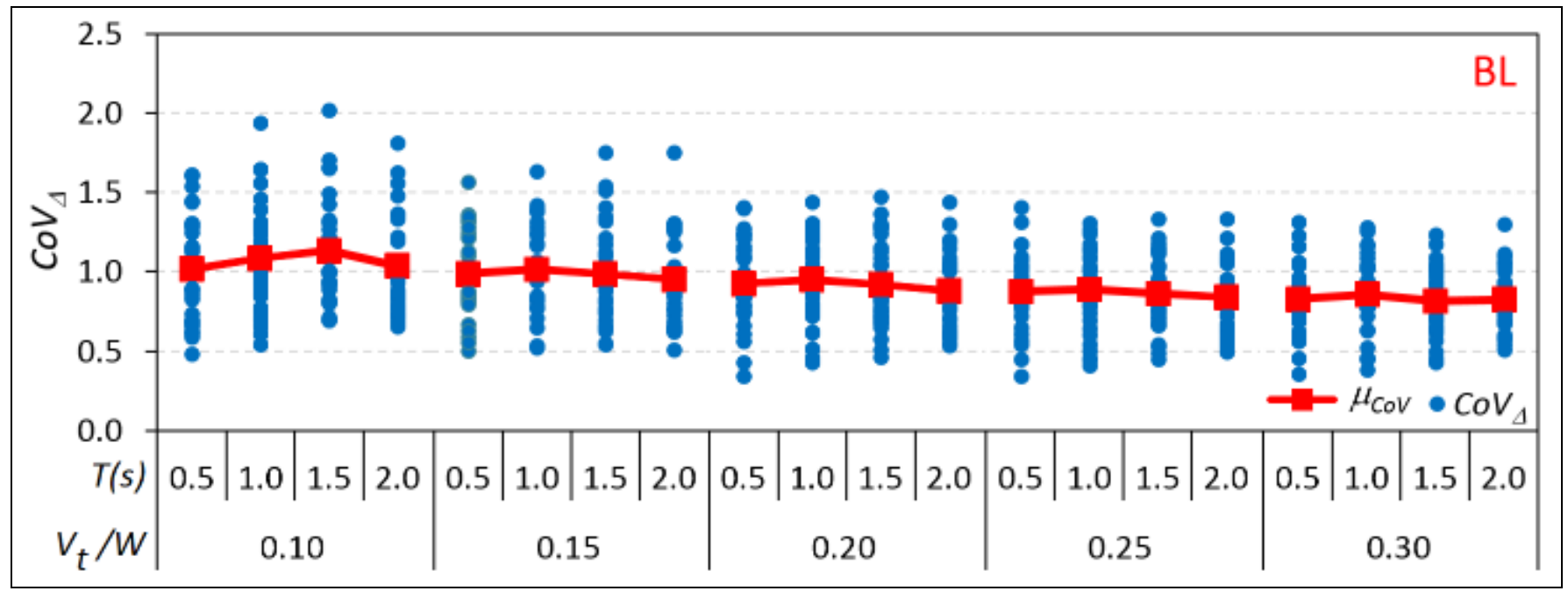

Figure 10. $\mathrm{CoV}_{\Delta}$ values for ZB soil classes, DD1 level and $\alpha=0.00$.

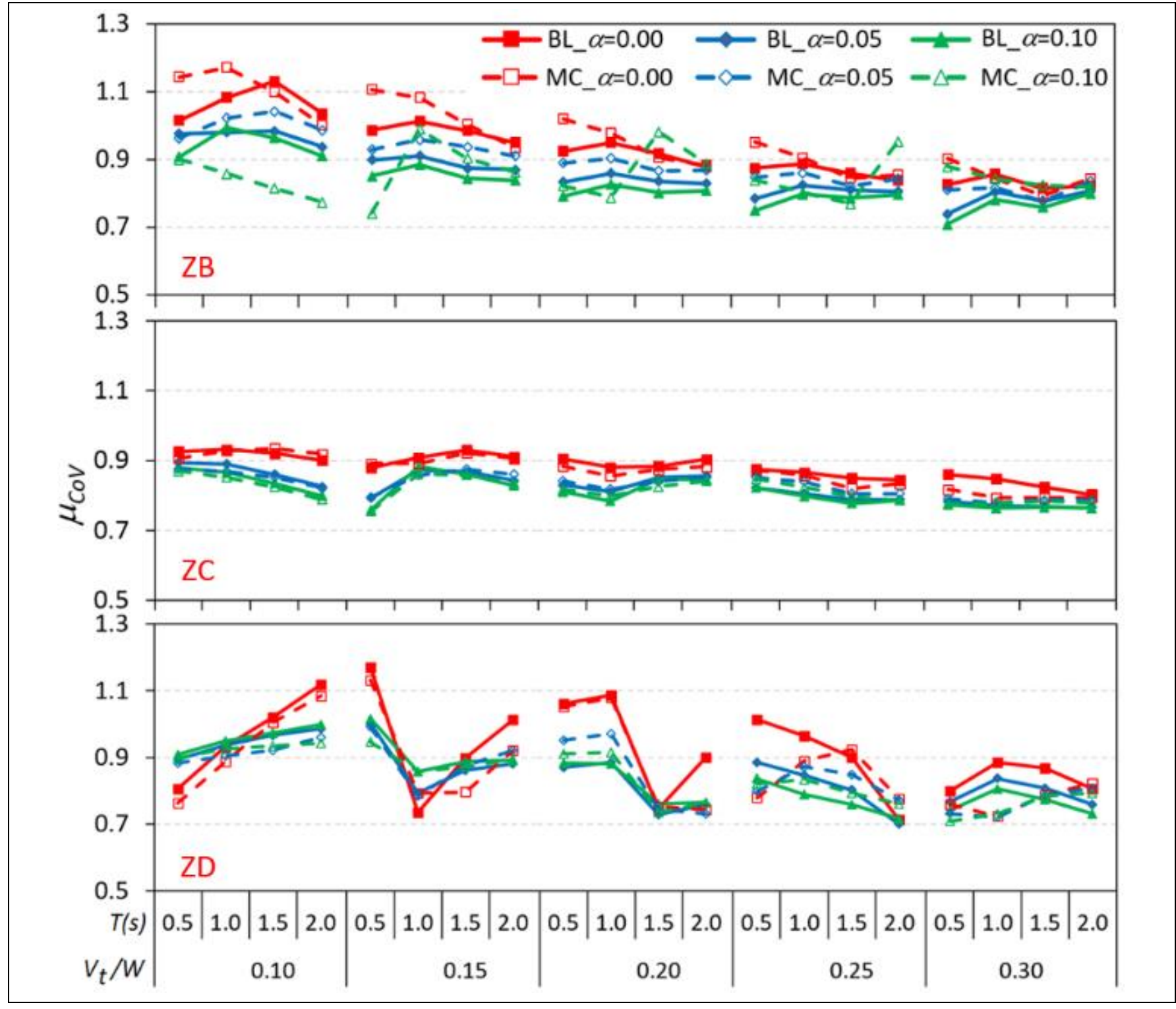

Figure 11. $\mu_{\mathrm{CoV}}$ values for DD1. 


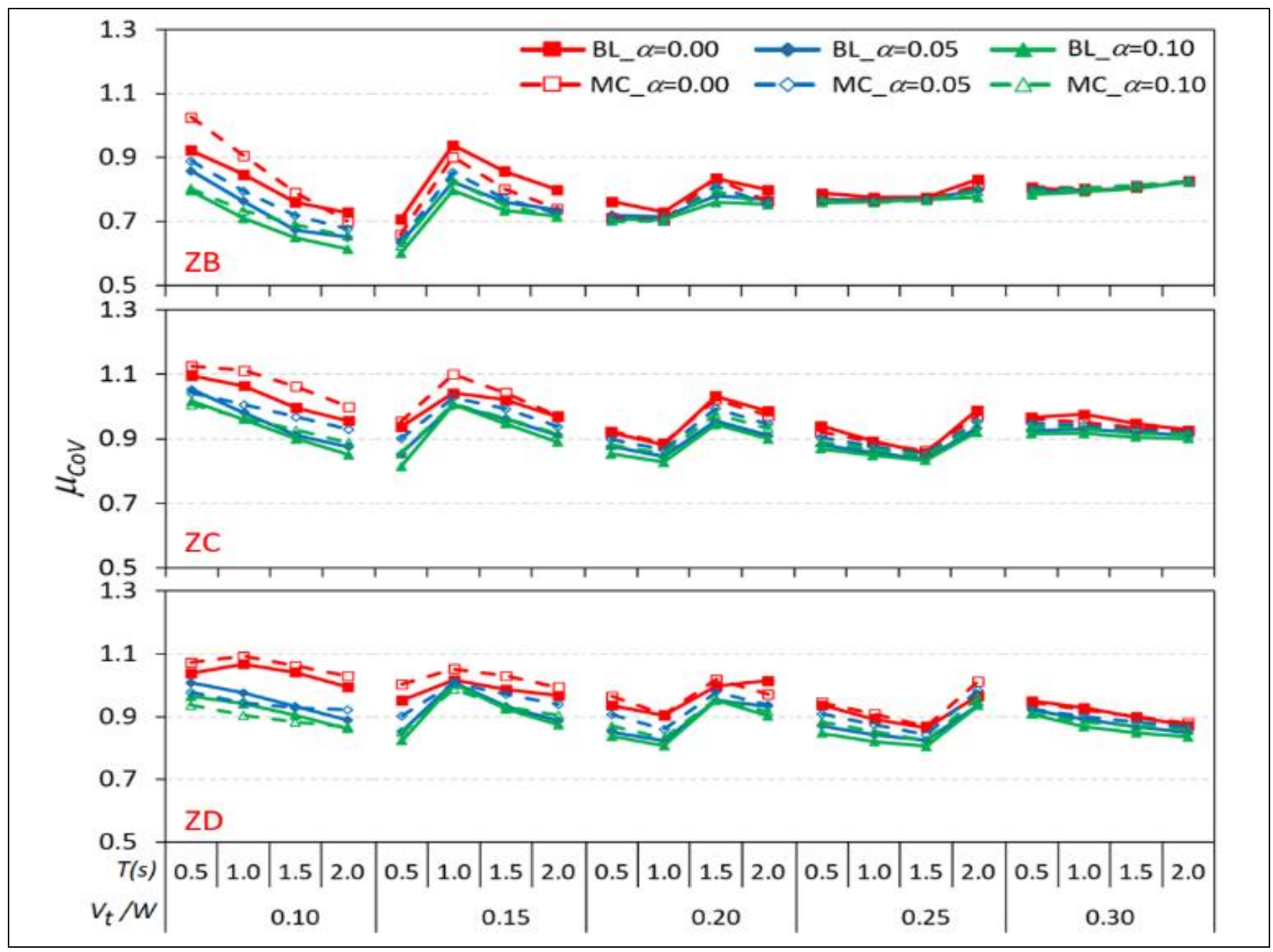

Figure 12. $\mu_{\mathrm{CoV}}$ values for DD2.

Observed values clearly show the gradual decreasing of $\mu_{\mathrm{CoV}}$ values. If the effect of hysteretic models and structural periods are investigated, it can be said that $\mu_{\mathrm{CoV}}$ values are not remarkably altered from hysteretic models and variation of $\mu_{\mathrm{CoV}}$ values are not related with structural periods. $\mu_{\mathrm{CoV}}$ values values were affected in different ways from soil types depending on earthquake level. $\mu_{\mathrm{CoV}}$ values of ZB are generally higher than other soil types for DD1 level while ZC and ZD are higher than ZB for DD2 level. This is also valid for both hysteretic models. Figs. 11 and 12 indicate that $\mu_{\mathrm{CoV}}$ values are frequently decreasing with increasing lateral strength capacity ratio

\section{Conclusions}

In the scope of the study, nonlinear dynamic analyses were conducted, and maximum displacement demands and their variation is investigated using TBEC compatible different earthquake records set. For this purpose, SDOF models are diversified using different $V_{t} / W$ and $T$. During the analysis of SDOF systems, Bilinear and Modified Clough hysteretic models with varying post-yield stiffness ratios were used and in total 120 distinct SDOF systems were analyzed. 30 different earthquake records containing eleven records were used for the analyses using two different earthquake levels and three different soil types. By this way, 237,600 dynamic analyses were performed by using 180 different earthquake sets when applied 120 SDOF systems.

Mean responses of each record set $\left(m_{\Delta}\right)$ is obtained by averaging the $\Delta_{\max }$ of eleven earthquakes in the set. Variation mean responses of each set $\left(\mathrm{CoV}_{\Delta}\right)$ is also investigated. In addition, median response values of the records set are obtained to compare with mean responses. Consequently, some salient observations of this study can be summarized as:

- It is possible to obtain distinct mean responses from different earthquake record sets although they are compatible with spectrum defined in TBEC,

- It was observed that displacement demands were decreased with increasing post-yield stiffness ratio,

- It was also observed that seismic demands of BL models are slightly higher or lower than MC model for the same SDOF system, earthquake level and local soil class. Thus, the effect of different hysteretic models on the mean responses of SDOF models was negligible,

- Comparison of mean and median responses of records set has shown that mean responses are consistently higher than median values. In other words, the use of mean responses results more conservative displacement demands than median one, 
- As expected, both mean and median responses increase from stiff soil to soft soil. These responses also increase with increasing level of seismic ground motion,

- $\quad$ TBEC compatible earthquake record sets mostly have high variations of maximum displacement demands. This situation states that dispersion of displacement demands of individual earthquake records in the sets is high,

- The variation of the seismic demands changes randomly depending on local soil class and earthquake level,

- Lateral strength ratio and post-yield stiffness are efficient on the variation of the demands while the structural period is ineffective,

- It is worth noting that record selection requirements of seismic codes mainly concentrate on nominal design/performance values. For this reason, mean spectrum of selected records are mostly conditioned at minimum level of UHS defined in the sesmic codes. As a natural consequence this situation, seismic demands estimated via selected records may generally be higher. It can be said that this situation allows practitioners to keep in safe side in design and assessment of structures. Nevertheless, application of appropriate upper limit for the mean spectrum of selected records may be beneficial to control mean displacement demands of the record sets.

The results of this study depend on the considered seismic intensity levels and local soil properties besides the properties of SDOF models such as vibration period, lateral strength ratio, post yield stiffness and hysteretic behavior model. Considering different level of seismic intensity, different local soil conditions and different properties of SDOF models would provide more remarkable results in the future studies. The different seismic demand properties can also be considered for the future studies.

\section{Author contribution statements}

Conceptualization and methodology, Mehmet PALANCI, Ahmet DEMIR and Ali Haydar KAYHAN, writing-original draft preparation, Mehmet PALANCI, Ahmet DEMIR and Ali Haydar KAYHAN, analytical computations, Ahmet DEMIR, writing-review and editing, Mehmet PALANCI, Ahmet DEMİR and Ali Haydar KAYHAN, visualization, Mehmet PALANCI and Ali Haydar KAYHAN. All authors have read and agreed to the published version of the manuscript.

\section{Ethics committee approval and conflict of interest statement}

There is no need to obtain permission from the ethics committee and there is no conflict of interest with any person/institution for the article prepared.

\section{References}

[1] Ghobarah A. "Performance-based design in earthquake engineering". State of Development Engineering Structures, 23, 878-884, 2001.

[2] SEAOC Vision 2000 Committee. "Performance-based seismic engineering". Report Prepared by Structural Engineers Association of California, Sacramento, California, USA, 1995.
[3] Demir A, Palanci M, Kayhan AH. "Global and interstory drift demands calculated for a mid-rise rc building using TBEC-2018 compatible real ground motion record sets". International Civil Engineering and Architecture Conference 2019, Trabzon, Turkey, 17-20 April 2019.

[4] Yön B, Oncu ME, Calayır Y. "Effects of seismic zones and local soil conditions on response of RC buildings". Građevinar, 67(06), 585-596, 2015.

[5] Yön B, Calayır Y. "The soil effect on the seismic behaviour of reinforced concrete buildings". Earthquakes and Structures, 8(1), 133-152, 2015.

[6] Applied Technology Council, "ATC-40: Seismic Evaluation and Retrofit of Concrete Buildings". California, USA, 1996.

[7] Riddell R, Garcia JE, Garces E. "Inelastic deformation response of SDOF systems subjected to earthquakes". Eartquake Engineering and Structural Dynamics, 31, 515-538, 2002.

[8] Hatzigeorgiou GD, Beskos DE. "Inelastic displacement ratios for SDOF structures subjected to repeated earthquakes". Engineering Structures, 31, 2744-2755, 2009.

[9] Kayhan AH, Demir A. "Tek serbestlik dereceli sistemlerde maksimum ötelenme talebi üzerinde çevrimsel davranış modellerinin etkisi". Pamukkale Üniversitesi Mühendislik Bilimleri Dergisi, 22(6), 442-453, 2016.

[10] Tekin G. Probabilistic Aerthquake Response Analysis of Single Degree of Freedom Structures. M.s Thesis, Boğaziçi University, Istanbul, Turkey, 2010.

[11] Mollaioli F, Bruno S. "Influence of site effects on inelastic displacement ratios for SDOF and MDOF systems". Computers and Mathematics with Applications, 55, 184-207, 2008.

[12] Liossatou E, Fardis MN. "Residual displacements of RC structures as SDOF systems". Earthquake Engineering and Structural Dynamics, 44(5), 713-734, 2015.

[13] Oviedo AJA, Midorikawa M, Asari T. "An equivalent SDOF system model for estimating the response of $\mathrm{R} / \mathrm{C}$ building structures with proportional hysteretic dampers subjected to earthquake motions". Earthquake Engineering and Structural Dynamics, 40(5), 571-589, 2010.

[14] Ministry of Public Works and Settlement. "TEC: Specification for Buildings to be Constructed in Seismic Zones". Ankara, Turkey, 2007.

[15] Baltzopoulos G, Baraschino R, Iervolino I, Vamvatsikos D. "Dynamic analysis of single-degree-of-freedom systems (DYANAS): A graphical user interface for OpenSees". Engineering Structures, 177, 395-408, 2018.

[16] Celep Z. Betonarme Taşıyıcı Sistemlerde Doğrusal Olmayan Davranış ve Çözümleme. 4. Baskı. İstanbul, Türkiye, Beta, 2017.

[17] Clough R, Johnston S. "Effect of stiffness degradation on earthquake ductility requirements". $2^{\text {nd }}$ Japan Earthquake Engineering Symposium, Tokyo, Japan, 1996.

[18] Graziotti F, Penna A, Magenes G. "A nonlinear SDOF model for the simplified evaluation of the displacement demand of low-rise URM buildings." Bulletin of Earthquake Engineering, 14(6), 1589-1612, 2016.

[19] Lignos DG, Krawinkler H. "Deterioration modeling of steel components in support of collapse prediction of steel moment frames under earthquake loading". Journal of Structural Engineering, 137(11), 1291-1302, 2010. 
[20] Kayhan AH, Korkmaz KA, Irfanoglu A. "Selecting and scaling real ground motion records using harmony search algorithm". Soil Dynamics and Earthquake Engineering, 31, 941-953, 2011.

[21] Iervolino I, Maddaloni G, Cosenza E. "Eurocode 8 compliant real record sets for seismic analysis of structures". Journal of Earthquake Engineering, 12(1), 54-90, 2008.

[22] Kayhan AH, Demir A, Palanci M. "Statistical evaluation of maximum displacement demands of SDOF systems by code-compatible nonlinear time history analysis". Soil Dynamics and Earthquake Engineering, 115, 513-530, 2018.

[23] Palanci M, Kayhan AH, Demir A. "A statistical assessment on global drift ratio demands of mid-rise RC buildings using code-compatible real ground motion records". Bulletin of Earthquake Engineering, 16(11), 5453-5488, 2018.

[24] Ambraseys NN, Douglas J, Berge-Thierry C, Suhadolc P, Costa G, Sigbjörnsson R, Smit P. "Dissemination of European strong-motion data, vol. 2". 13 ${ }^{\text {th }}$ World Conference on Earthquake Engineering, Vancouver, Canada, 1-6 August 2014.

[25] Akkar S, Sandıkkaya MA, Senyurt M, Sisi AA, Ay BÖ, Traversa P, Douglas J, Cotton F, Luzi L, Hernandez B, Godey S. "Reference database for seismic ground-motion in Europe (RESORCE)". Bulletin of Earthquake Engineering, 12(1), 311-339, 2014.
[26] Ancheta TD, Darragh RB, Stewart JP, Seyhan E, Silva WJ, Chiou BSJ, Wooddell KE, Graves RB, Kottke AR, Boore DM, Kishida T, Donahue JL. "NGA-West2 database". Earthquake Spectra, 30(3), 989-1005, 2014.

[27] Ministry of Public Works and Settlement. "TBEC: Turkish building earthquake code". Ankara, Turkey, 2018.

[28] Palanci M, Kalkan A, Senel SM. "Investigation of shear effects on the capacity and demand estimation of RC buildings". Structural Engineering and Mechanics, 60(6), 1021-1038, 2016.

[29] Demir A. Deprem Yönetmeliği İle Uyumlu İvme Kaydı Setleri Kullanılarak Doğrusal Olmayan Dinamik Ötelenme Taleplerinin İstatistiksel Olarak Değerlendirilmesi. Yüksek Lisans Tezi, Pamukkale Üniversitesi, Denizli, Türkiye, 2015.

[30] Kayhan AH. "Armoni araştırması ile ivme kaydı seçimi ve ölçeklendirme”. IMO Teknik Dergi, 23, 5751-5775, 2012.

[31] Jacobson R. Microsoft Excel-Visual Basic for Applications. Washington, USA, Microsoft Press, 1995.

[32] Ministry of Interior Disaster and Emergency Management Presidency. "Earthquake Hazard Map of Turkey". https://tdth.afad.gov.tr/ (01.06.2019). 